\title{
\begin{tabular}{l|l}
\hline T $D D$ & Jurnal Inovasi, Evaluasi, dan Pengembangan Pembelajaran \\
\hline Journal of Innovation, Evaluation and Learning Development
\end{tabular}
}

\section{Efektivitas Media Pembelajaran Berbasis Daring di Masa Pandemi Covid-19 (Studi Kasus pada Siswa SMP)}

\author{
M. Nur Imansyah \\ Program studi Pendidikan Teknologi Informasi, STKIP Yapis Dompu \\ E-mail: mnurimansyah000@gmail.com
}

Article History: Received: 2021-08-19 || Revised: 2021-08-20 || Published: 2021-08-20

Sejarah Artikel : Diterima: 2021-08-19 || Direvisi: 2021-08-20 || Dipublikasi: 2021-08-20

\begin{abstract}
This study aims to answer the problem formulation of the effectiveness of using courage-based learning media during the covid-19 pandemic at SMPN 01 Dompu in the 2020/2021 learning year. Data collection carried out by researchers was by observation, interviews and documentation. The results showed that the learning process boldly using Google Classroom was not effective because of the many factors and obstacles experienced by students or students during the bold learning process. This is also a very important problem for students, because students find it difficult to always be active in the Google Classroom learning media, while not all students have internet quota for them to study boldly. Moreover, at this time the learning process is not far from the internet network
\end{abstract}

Keywords: Effectiveness, Google, Classroom

\begin{abstract}
Abstrak
Penelitian ini bertujuan untuk menjawab rumusan masalah Efektivitas penggunaan media pembelajaran berbasis daring pada masa pandemic covid-19 di SMPN 01 Dompu tahun Pembelajaran 2020/2021 Pengumpulan data yang dilakukan peneliti yaitu dengan Observasi, wawancara dan dokumentasi. Hasil penelitian menunjukan bahwa proses pembelajaran secara daring menggunakan Google Classrrom tidak efektif karena banyaknya faktor dan kendala yang di alami siswa atau peserta didik saat proses pembelajaran daring. Hal ini pun menjadi permasalahan yang sangat penting bagi siswa, karena siswa dituntut untuk selalu aktif dalam media pembelajaran Google Classroom, sedangkan tidak semua siswa memiliki kuota internet untuk mereka belajar daring. Apalagi saat ini proses pembelajaran tidak jauh dari jaringan internet.
\end{abstract}

Kata kunci: Efektivitas, Google, Classroom

\section{PENDAHULUAN}

Lembaga pendidikan merupakan salah satu lembaga yang memiliki konstribusi terbesar dalam memajukan bangsa dan negara dari segala aspek.Karena generasi penerus bangsa di didik dan dibimbing pada lembaga pendidikan, dengan demikian dapat diambil sebuah kesimpulan bahwa maju tidaknya sebuah negara tidak terlepas dari maju tidaknya dunia pendidikan, dengan adanya wabah Corona Virus Disease (Covid-19) bermula timbul di Wuhan, Cina sejak 31 Desember 2019 dan telah di umumkan sebagai pandemi oleh organisasi kesehatan dunia Sohrabi, et al., (2020). Dampak virus corona akhirnya mempengaruhi hingga dunia pendidikan.Aktivitas pembelajaran tidak dapat dilakukan lagi secara tatap muka tetapi dilakukan secara daring (dalam jaringan) dengan menggunakan berbagai aplikasi sebagai media pembelajarannya, pembelajaran daring menghubungkan peserta didik dengan sumber belajarnya (database, pakar/instruktur, perpustakaan) yang secara fisik terpisah atau bahkan berjauhan namun dapat saling berkomunikasi,berinteraksi atau berkolaborasi (secara langsung dan tidak langsung), berdasarkan observasi awal pada tanggal 06 Oktober 2020.

Selama pandemi ini proses pembelajaran di SMP Negeri 01 Dompu didominasi penggunaan media atau aplikasi Google Classroom dan pesan Whatsapp, dimana dalam presentasi penggunaan media whatsapp sebanyak 10,9\% Sedangkan penggunaan media Google Classroom 89,0\% pengguna, dari jumlah 73 guru GTT (guru tidak tetap) maupun guru GT (guru tetap) di SMP Negeri 01 Dompu, 
dikarenakan sebagian guru merasa dengan menggunakan applikasi Whatsapp lebih efektif ketimbang menggunakan media pembelajaran Google Classroom, sehingga Kemampuan guru dalam menyampaikan pelajaran merupakan faktor yang sangat penting dalam menentukan tingkat keberhasilan atau tidaknya suatu proses pembelajaran menggunakan media daring dalam bentuk Google Classroom, seorang guru dituntut untuk mampu mengemas materi dengan cermat dan memperhatikan metode penyampaian dengan baik.

Pendidikan merupakan usaha sadar dalam membina dan mengembangkan harkat dan martabat manusia secara utuh dan menyeluruh dengan menarik, menyenangkan dan menggembirakan, itu mengacu kepada terpadunya perkembangan fisik, mental spritual atau perkembangan aspek-aspek psikologis dan aspek fisiologis pada tiap individu, sehingga pada akhirnya terbentuk dan terbina pribadi matang pada individu yang bersangkutan, adapun kata terbentuk mengacu kepada perkembangan semua aspek aspek kognitif, efektif, pisikomotorik maupun fisik, bukan salah satu atau beberapa aspek saja, pendidikan harus tetap diupayakan dan terus dilakukan perbaikan setiap harinya, salah satu cara untuk mencapai tujuan dari pendidikan adalah menciptakan suasana belajar yang mudah dan menyenangkan bagi perserta didik sehingga tujuan dari pembelajaran dapat tercapai. Pada masa Covid-19 Proses pembelajaran akan lebih mudah ketika menggunakan media yang sesuai, penggunaan media berupa media daring (online) seperti whatshap akan memudahkan dalam pembelajaran.

Dengan tuntutan Kurikulum K13 yang men-syaratkan guru dan siswa terampil menggunakan teknologi dalam pembelajaran, baik sebagai media, maupun sebagai bahan pembelajaran. Oleh karena itu guru dan siswa harus memiliki keterampilan dalam bidang TI Saroh Jarmin, (2018), yang dimana guru hanya menerangkan materi dengan singkat, kemudian siswa di tuntut untuk belajar sendiri dan mencari informasi terkait materi yang telah disampaikan, siswa juga harus berpikir kritis dan memiliki keterampilan dalam menyampaikan materi sehingga membentuk sikap konstribusi, Matematika merupakan salah satu mata pelajaran yang cukup sulit diajarkan secara daring. Dikarenakan selama ini masih banyak peserta didik yang menganggap matematika sebagai pelajaran yang sulit sebagaimana pendapat Auliya (2016), karena karakteristik matematika yang bersifat abstrak, logis, sistematis, dan penuh dengan lambang serta rumus yang membingungkan, kesulitan tersebut menuntut kreativitas guru mata pelajaran untuk mengembangkan pembelajarannya, baik dalam hal metode maupun media yang digunakan, berdasarkan permasalahan diatas penulis merasa tertarik untuk meneliti lebih dalam mengenai "Efektivitas penggunaan media pembelajaran berbasis daring pada masa pandemi covid-19 (studi kasus terhadap SMP Negeri 01 Dompu)".

\section{METODE PENELITIAN}

Jenis penelitian ini adalah kualitatif deskripsi Adapun yang dijadikan subjek penelitian ini meliputi: 1) Kepala sekolah 2) 1 Guru mata pelajaran Matematika yang berkriterial PNS pada kelas VIII SMP Negeri 01 Dompu 3) Siswa kelas di SMP Negeri 01 Dompu, sedangkan subjek penelitian ini dibagi dalam beberapa karakteristik : 3 siswa yang memiliki prestasi dalam kelas dan 2 siswa kurang prestasi dalam kelas, penentuan informan yang sering di gunakan dalam penelitian kualitatif adalah teknik purposive sampling, yaitu teknik pengambilan sampel sumber data didasarkan pertimbangan dan tujuan tertentu (orang yang dipilih betul-betul memiliki kriterial), sebagai sempel informan ini di butuhkan, untuk mengetahui Efektivitas penggunaan media pembelajaran berbasis daring pada masa pandemi covid-19 di SMP Negeri 01 Dompu, sumber data yang digunakan sumber data primer di proleh hasil dari wawancara atau narasumber dan sumber data skunder berupa dokumentasi, ataupun profil sekolah, dengan teknik analisis data ada tiga sebagai penunjang yaitu, reduksi data, penyajian data dan kesimpulan untuk mendapatkan hasil data yang valid.

\section{HASIL DAN PEMBAHASAN}

\section{A. Hasil Penelitian}

SMP Negeri 01 Dompu beroperasi sebagai institusi pendidikan pada tahun ajaran 1956 di bawah pimpinan kepala sekolah saleh amin, berdirinya SMP Negeri 01 Dompu tidak terlepas dari hubungan usaha pemerintah, tokoh-tokoh masyarakat, dan orang-orang yang bersangkutan di kabupaten Dompu saat itu untuk memajukan pendidikan didaerah kabupaten Dompu, agar bisa 
bersaing dengan sekolah lain, SMP Negeri 01 Dompu senantiasa terus berusaha untuk mengukuhkan eksistensinya dan meningkatkan kualitas menjadi salah satu sekolah favorit terpandang dan beribawa, Sehingga SMP Negeri 01 Dompu telah berhasil mengukir prestasi baik dalam bidang akademik maupun non akademik di tingkat provinsi, kota dan kabupaten dengan status Negeri, berakreditasi A dan yang memiliki kode NPSN 50203721 dan sudah berstatus, dengan memiliki Ijin Operasional sejak pada tahun 1910-01-01, Sampai saat ini. SMPN 01 Dompu belum terdaftar sebagai ISO, hal ini tentu saja menjadi kebanggaan tersendiri oleh para alumni SMP Negeri 01 Dompu yang sekarang telah sukses menjadi orang-orang yang sangat terpandang.

Dari seluruh siswa di SMPN 01 Dompu yang memiliki siswa sebanyak 941 siswa hanya 887 siswa yang terdata penghasilan orang tua, dari seluruhnya ada 17 siswa dengan penghasilan 5 juta perbulan yang di katakan cukup mampu sedangkan160 siswa yang memiliki penghasilan orang tua di atas 2 juta dalam satu bulan, dan 72 siwa yang memiliki penghasilan orang tua 1 juta sedangkan yang 189 siswa dengan penghasilan orang tua 500 ribu ke yang di katakan kurang mampu, dari paparan di atas ada 52 siswa yang tidak terdata di karenakan siswa pindahan dan siswa transfer., Dilihat dari mayoritas penghasilan dari orang tua siswa dapat dikataka bahwa sebagaian besar siswa berasal dari keluarga mampu.Menurut Badan Pusat Statistik (BPS), Suhsriysnto bahwa pendapatan yang di bawah 1.000 .000 perbulan maka keluarga tersebut di katakan tidak mampu. Jika dalam satu keluarga dengan pendapatan 1.600 .000 perbulan makan ia di katakan keluarga mampu, sehingga siswa-siswi di SMP Negeri 01 Dompu di kategorikan mampu dalam menggunakan media Google Classrom, hal ini Sesuai dengan penghasilan orang tua siswa, Penelitian ini bertujuan untuk mengetahui efektivitas penggunaan media pembelajaran berbasis daring pada masa pandemic covid-19 pada SMPN 01 Dompu. Dari hasil wawancara yang di dapatkan peneliti dari beberapa narasumber yang terdiri kepala sekolah, guru dan 3 siswa berprestasi, 2 siswa yang kurang berprestasi pada kelas VIII B.

\section{Faktor munculnya kesulitan dalam pelaksanaan pembelajaran daring.}

Faktor munculnya kesulitan dari sisi guru dan siswa yaitu guru harus memulai dari awal membuat file materi dll, siswa terbatasnya akses internet dan bimbingan dari orang tuadimana ada beberapa peserta didik yang tidak memiliki akses internet sehingga mengakibatkan peserta didik tersebut tidak dapat mengikuti kelas daring.

\section{Solusi yang dilakukan untuk mengatasi kesulitan yang dihadapi.}

Untuk menyikapi kemungkinan munculnya kendala dari sisi guru yaitu tetap menerima kembali tugas-tugas dari siswa yang terlambat bergabung, sedangkan dari sisi siswanya harus mencari referensi dari youtobe dan belajar kelompok dengan teman di luar GC.

\section{B. Pembahasan}

\section{Pembelajaran secara daring yang tidak Efektif}

Efektivitas pembelajaran menurut Rohmawati (2015:17) adalah ukuran keberhasilan dari suatu proses interaksi antar siswa maupun antara siswa dengan guru dalam situasi edukatif untuk mencapai tujuan pembelajaran. Dampak yang dirasakan murid pada proses belajar pembelajaran di rumah ini belum ada budaya belajar jarak jauh karena selama ini sistem belajar dilaksanakan adalah melalui tatap muka, murid terbiasa berada di sekolah untuk berinteraksi dengan teman-temannya, bermain dan bercanda gurau dengan teman-temannya serta bertatap muka dengan para gurunya, dengan adanya metode pembelajaran jarah jauh membuat para murid perlu waktu untuk beradaptasi dan mereka menghadapi perubahan baru yang secara tidak langsung akan mempengaruhi daya serap belajar mereka.

\section{Kelebihan pembelajaran berbasis daring pada masa pandemi covid-19 menggunakan} media pembelajaran Google Classroom.

Pada masa pandemi Covid-19 yang masih merambank di indonesia, kegiatan pembelajaran yang dilakukan di sekolah dan kampus sekarang dilakukan secara daring atau online untuk menjaga jarak agar tidak menularnya virus Covid-19, sehingga pemerintah mencari alternatif lain agar tetap terjaganya proses pembelajaran yaitu pembelajaran secara online atau daring, dengan adanya proses pembelajaran secara daring kini guru dan siswa tetap melakukan aktivitas belajar seperti biasa walaupun di rumah saja, pihak sekolah SMP Negeri 01 Dompu menyelenggarakan kepada guru untuk menggunakan Google Classroom sebagai media pembelajar, pada saat 
pandemi covid-19 alasan kepala sekolah menggunakan media Google Classroom sebagai media belajar dikarena Google Classroom mudah di gunakan dan tidak boros pemakaian kuota internet karena siswa dapat melihat kembali tugas yang telah diberikan sebelumnya, dengan menggunakan Google Classroom juga tugas-tugas yang telah di apload dapat terarah, Google Classroom merupakan salah satu aplikasi yang sederhana dan mudah dipahami dalam penggunaannya.Cukup dengan menggunakan akun email google Afrinaty, (2020), selain kapasitas ruang yang kecil yaitu 13 MB fitur dan menu yang terdapat pada Google Classroom juga tidak begitu rumit sehingga gampang untuk digunakan bagi guru maupun siswa.

Aplikasi google classroom memiliki fitur yang mendukung proses pembelajaran. Menurut Wikipedia (2019) ada beberapa fitur yang ditawarkan google classroom antara lain adanya fitur assignment (pemberian tugas), adanya proses pengukuran (grading) dengan skema penilaian yang berbeda, komunikasi dua arah antara guru dengan siswa yang didukung oleh google drive, adanya fitur arsip program dan fitur aplikasi google classroom dapat diakses dengan perangkat android dan iOS, kesemua fitur tersebut tersedia di google classroom dan dapat digunakan oleh guru selama proses pembelajaran Iskandar dkk, (2020).

\section{SIMPULAN DAN SARAN}

\section{A. Simpulan}

Berdasarkan hasil penelitian kualitatif dalam mendeskripsikan dengan teknik observasi, wawancara dan dokumentasi yang dilaksanakan di SMP Negeri 01 Dompu, tentang Efektivitas penggunaan media pembelajaran berbasis daring pada masa pandemi covid-19 (Studi kasus pada SMP Negeri 01 Dompu) Tahun Pelajaran 2020-2021, selama masa pandemi covid-19 pihak SMP Negeri 01 Dompu telah menyatakan bahwa media pembelajaran yang mereka gunakan yaitu Google Classroom setelah peneliti mendapatkan informasi dari narasumber bahwa proses pembelajaran secara daring, tidaklah efektif karena banyaknya faktor dan kendala yang di alami siswa atau peserta didik dalam melaksanakan pembelajaran secara daring, siswa tidak bisa berinteraksi secara langsung dengan guru maupun temanya. Sehingga siswa lebih tertarik belajar tatap muka di sekolah, apa lagi saat ini guru dan siswa di tuntut untuk belajar secara daring sehingga siswa harus benar-benar ikut bergabung dalam media online atau belajar secara daring menggunakan Google Classroom, sedangkan tidak semua siswa bisa bergabung dalam media Google Classroom karena memiliki banyak kenadala yang di hadapi oleh siswa setiap individu.

\section{B. Saran}

Adapun saran yang diberikan oleh peneliti agar pembelajaran matematika kedepannya lebih efektif, walaupun tidak seefektif pembelajaran tatap muka yakni: (1) Saran bagi kepala sekolah Pihak kepala sekolah merupakan pimpinan sebagai kepala sekolah penyelenggara atau mengatur dalam bidang akademi maupun non akademik sehingga perlu memberikan arahan dan motivasi kepada guru-guru untuk slalu berusaha mengembangkan model atau metode pembelajaran baru, dan gurupun tidak hanya fokus mengajar pada satu media ajar melainkan media pembelajaran lainnya seperti aplikasi Zoom Meeting dan aplikasi tatap muka lainnya, (2) Saran bagi guru, Untuk memaksimalkan materi agar dicermat oleh siswa dengan baik, maka seharusnya guru tidak hanya terus menerus memberikan tugas kepada siswa.Namun, guru harus tetap memberikan pengajaran dan pemahaman kepada siswa. Dengan memberikan contoh lebih dari satu agar siswa paham dengan materi yang telah disampaikan dan guru tidak hanya fokus menggunkan media Google Classroom, tetapi menggunkan media lain agar siswa paham dengan tugas yang diberikan, (3) Saran bagi Peneliti, Untuk peneliti teruslah menempuh pendidikan dan tetap melanjutkan membuat karya tulis ilmiah yang nantinya bisa bermanfaat dalam dunia pendidikan. Mengingat banyaknya kekurangan dalam penelitian ini, baik dari hal informasi mengenai Efektivitas penggunaan media pembelajaran berbasis daringpada masa pandemi Covid-19 dalam pembelajaran matematika, atau hal lainnya, diharapkan adanya penelitian tentang Efektivitas penggunaan aplikasi google classroom dalam pembalajaran daring dengan karya ilmiah yang berbeda dan berbobot. 


\section{DAFTAR RUJUKAN}

Aji Wahyu Fatma Dewi.(2020).Dampak covid-19 terhadap implementasipembelajaran daring di sekolah dasar. Universitas Kristen Satya Wacana.

Astuti dewi aprilia.(2020)."Efektivitas penggunaan media belajar dengan sistem daring ditengah pandemi covid-19" Afrinaty,(2020)Google Classroom merupakan salah satu aplikasi yang sederhana dan mudah dipahami dalam penggunaannya.(hal.142) Cukup dengan menggunakan akun email google. Fakultas ilmu Pendidikan, Universitas Negeri Malang.

Faizah lailatu.(2020). "Implementasi Aplikasi Google Classroom Dalam Pembelajaran Daring Matematika Masa Pandemi Covid-19 (Studi Analisa Kreativitas Mengajar Guru Matematika di SMP Negeri 4 Salatiga Tahun Pelajaran 2019/2020)". Hakim (2016:2) google classroom adalah layanan berbasis internet yang disediakan oleh Google sebagai sebuah sistem Elearning.(hal.11). Fakultas Tarbiyah Dan Ilmu Keguruan (Ftik) Institut Agama Islam Negeri (Iain) Salatiga

Fitriyani Nur Ivah.(2020).Model pembelajaran online (daring) menggunakan google classroom pada mata pelajaran pendidikan agama islam dan budi pekerti di smpn 4 ambarawa tahun ajaran 2020/2021. Fakultas Tarbiyah Dan Ilmu Keguruan Institut Agama Islam Negeri Salatiga.

Gusti Mahardika Alif.(2017). Implementasi jurnalisme visual di media daring: studi kasus kolom sketsatorial di rappler Indonesia.Craing (2005:89) media daring bukanlah tampa kelemahan(hal.20-21).Universiatas Multimedia Nusantara.

Hamidah afreni, sadikin ali.(2020).Pembelajaran Daring di Tengah Wabah Covid-19. Iftakhar (2016) Misalnya kelas-kelas virtual menggunakan layanan Google Classroom, Edmodo, dan Schoology, dan aplikasi pesan instan seperti Whatsapp.(hal.1-2).Program studi pendidikan Biologi FKIP Universitas Jambi.

Hammi Zedha.(2017).Implementasi Google Classroom pada kelas XI IPA MN 2 KUDUS. Herman,(2014) Selain itu, google classroom bisa menjadi sarana distribusi tugas, submit tugas bahkan menilai tugas-tugas yang dikumpulkan.(hal.27). Fakultas ilmu pendidik Universitas Negeri Semarang.

Hastomo Siddiq Aldila.(2013).Efektivitas media pembelajaran e-learning terhadap prestasi belajar pendidikan agama islam siswa di sma negeri 1 yogyakarta.Fakultas Ilmu Tarbiyah Dan Keguruan Universitas Islam Negeri Sunan Kalijaga Yogyakarta.

Kurnia Dewi Shinta.(2020).Efektivitas e-learning sebagai media Pembelajaran mata pelajaran tik Kelas XI di SMA Negeri 1 Depok.Hidayat (1986) efektivitas adalah suatu ukuran yang menyatakan seberapa jauh target (kuantitas,kualitas dan waktu) telah tercapai.(hal.9).Fakultas Teknik Universitas Negeri Yogyakarta

Makrufa Nahiyatu Siti.(2020) "Analisis Kesulitan Guru Matematika Mts Pangeran Diponegoro Salaman Tahun Pelajaran 2019/2020 Dalam Menerapkan Pembelajaran Daring (Dalam Jaringan) Selama Masa Pandemi Virus Corona". Moleong (2017: 6) mendefinisikan penelitian kualitatif sebagai penelitian yang bermaksud untuk memahami fenomena tentang apa yang dialami oleh subjek. (hal.44-47). Fakultas Tarbiyah Dan Ilmu Keguruan Institut Agama Islam Negeri (Iain) Salatiga

Meleong, L. J. (2004). Metodogi penelitian kualitatif edisi revisi.Bandung: PT. Remaja Rosdakarya Offset.

Mustakin.(2020)."Efektivitas pembelajaran daring menggunakan media online selama pandemi covid-19 pada mata pelajaran matematika" 
Nuzula, Ahmad Firdausi.(2020). Efektivitas Pembelajaran Daring Dengan Menggunakan Google Classroom pada mata pelajaran matematika di madrasah.Universitas bumi gora mataram.

Ramadhani Mawar.(2012).Efektivitas penggunaan media pembelajaran E-learning berbasis web pada pelajaran teknologi informasi dan komunikasi terhadap hasil belajar siswa kelas X SMA Negeri 1 Kalasan.Fakultas teknik Universitas Negeri Yogyakarta.

Sugiyono. (2017). Metode Penelitian Kuantitatif, Kualitatif, Dan R\&D. Bandung:

Sugiyono.(2014).Metodelogi Penelitian Pendidikan. Bandung: Alfabeta.

Sugiyono.(2015).Metode Penelitian Pendidikan (Pendekatan Kuantitatif, Kualitatifdan R\&D). Bandung: Alfabeta.

Sulistyowati Dyah Ayu.(2015).Penggunaan media pembelajaran oleh guru pada program keahlian administrasi perkantoran di SMK Negeri 7 Yogyakarta. Suranto (2005: 18) mengemukakan pengertian "Media adalah sarana yang digunakan untuk menyampaikan pesan dari komunikator kepada komunikan.(hal10-12).Fakultas Ekonomi Universitas Negeri Yogyakarta.

Wahyudin Darmalaksana. (2020). Analisis pembelajaran online masa WFH pandemic covid-19 sebagai tantangan pemimpin digital abad 21. UIN sunan gunung Djati Bandung.

Widiyono Aan.(2020). Efektivitas perkuliahan daring (online) pada mahasiswa PGSD di saat pandemi covid-19. Sohrabi, et al., (2020) Wabah Covid-19 bermula timbul di Wuhan, Cina dan telah diumumkan sebagai pandemic oleh organisasi kesehatan dunia.(hal.169).PGSD,FTIK, UNISNU Jepara.

Yolandasari Berliana Mega. (2020). Efektivitas pembelajaran daring dalam pembelajaran Bahasa indonesia di kelas II A Mi Unggulan Miftahul Huda Tumang Cepogo Boyolali Tahun pelajaran 2019/2020.Efendi(2008:140) kekurangan Google Classroom. 